\title{
シンセティックジェットのコアンダ効果に関する研究
}

\section{Numerical Study on Coanda Effect of Synthetic Jet}

\author{
O正 西部 光一（工学院大院）学 中川 盟士（工学院大院） 正 岡安 晋平（工学院大院） \\ 正 佐藤光太郎（工学院大） 正 横田 和彦 (名工大)
}

\begin{abstract}
Koichi NISHIBE, Graduate School of Engineering, Kogakuin University, Nishi-Shinjuku 1-24-2, Shinjuku-ku, Tokyo Chikashi NAKAGAWA, Graduate School of Engineering, Kogakuin University Shimpei OKAYASU, Graduate School of Engineering, Kogakuin University Kotaro SATO, Kogakuin University Kazuhiko YOKOTA, Nagoya Institute of Technology, Gokiso-cho, Showa-ku, Nagoya, Aichi
\end{abstract}

Key Words : Synthetic Jet, Coanda Effect, Momentum, Velocity Distribution, Reynolds Number, Stokes Number

\section{1. 緒譣}

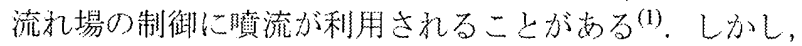
晬流生成にはコンブレッサなどを利用した流体供給が必要 であることから，システム全体としては複雑になり，小型 化・軽量化に適している上住い難い。乙こで最近では連続 噴流に代えてシンセティックジェットを利用する流体制穊 が武多られている(2)-(4)。シンセティックジェットは吸引よ噴

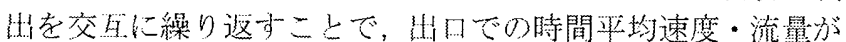

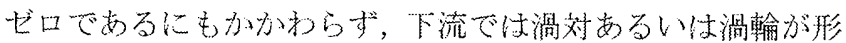
成され連続噴流同様の速度分布・実質流量が生成される流れ である。アクチュエータにはブラズマ方式やビェゾ駆動型, スピーカー型などが考案されているが，いずれも回転部がな いため小型化・軽丵化に適している。シンセティックジッ 下の基本的特性についてはこれ来でもいくつか報答肪六さ

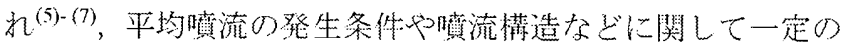
成果架得られている。し劦し，詳細な発生機構や流動特性に は未格不明な点が多く残されており，なかでもコアンダ效果 に代表されるようなシンセテイックジェットと境界面と丁 渉について報告した例童著者らは確認していない。

そこで，本研究ではシンセテイックジェットと境界面との

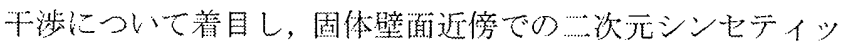
クジェットの流動特性の解明を試名る。主として数值シミュ レーション存用いてフローバターンに及ぼす $K\left(K=R e / S^{2}\right.$ で定義(5)され無次元ストロークに相当するバラメー夕）の影 響羊びに連続噴流とシンセティックジェットの顀流構造の 同琵について議論する。

\section{2. 数值シミュレーションモデル}

数值シミュレーションには, 非構造格了系熱流体解析シス テム SCRYU/Tetra for Windows [(株)ソフトウェアクレイド ル＼cjkstart在用いた，本研究では乱流モデルは用いずに，二次元非 圧縮粘性流れ老仮定して流れ埸の解析を行った。

图 1 に, 訃算領域上境界条件の一例 $(H / b=20$ の場合 $)$ 在昰 寸。境界条件上して噴流且口（スロット）で流速を与え，

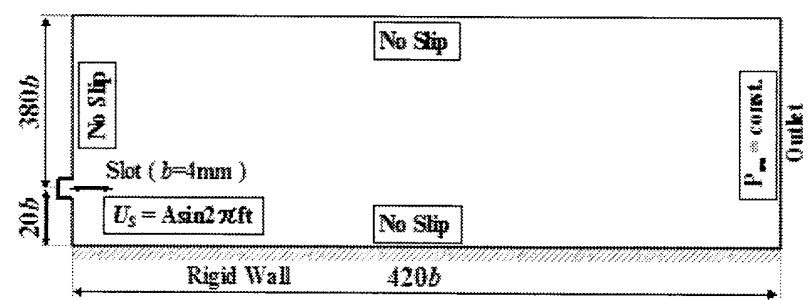

Fig.1 Numerical simulation domain and boundary condition
計算領域出口境界では压力一定条件を与えた，固体壁面と反 対側の外部境界位圈はスロット中心より $380 b$ とし，下流側 出口位犆は $420 b$ した。。な扮，本研究では図1の上壁，下

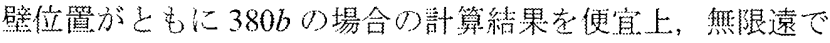
の結穜しして採用した。また，本計算に用いたグリッド数は 約 200,000 で㚣り，スロット幅 $b=4 \mathrm{~mm}$ として計算した。 レ イノルズ数 $R e=U b / v$ は，代表速度として連続噴流では嗢流 速度 $U_{J}$, シンセティックジェットでは吹き纯し時の速度（正 の速度成分）の双老周期で時間平均した速度 $U_{0}=f L_{0}=A / \pi$ 走与 えた ${ }^{(6)}$. 本研究では主に $R e=133$ の絽果について報等する。

\section{3. 結果及ひ考察}

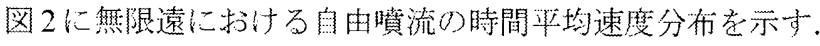
(a)は連続潩流で，(b)と(c)はシンセデイックジェットの場合 である. (b)と(c) では振動数の多が鼠なり，(b)は $K=2.4$, (c) は $K=1.0$ の計算結果である。ここで，Kは $K=2 U_{0} b / v S^{2}$ で定 義され，器次元ストロークに相当する。し， $S=\left[2 \pi f b^{2}\right.$ $v]^{1 / 2}$ はストークス数上古万( ${ }^{(5)}$. 本計算条件で(a)と(b)の下流 側 $x / b>5$ で数似の速度分析を示している。 L交し， $x / b<5$ の場會，(a)の連続浻流では逆流为見られないのに対して，(b) のシンセティックジェットでは䞇流近傍に明確な逆流域が 形成され，一方で，噴流中心の最大流速は連続䧸流に比較し て大さくなっている様子汃観察される。(c)の条件で惊同じ Re 数で文っても(a)，(b)七同程度の䨘流量は得られない。 噴流幅については(a)，(b)と比べ急激に拡大していることがわ かり。この傾向は㗹の研究者的上万報告とも一致している。 ただし，本図で示古範国では下流でも噴流の速度分布を形成 している样子は確譛できる。このことからシンセティックジ エットの基本流動特性は $K$ に大きく依存していることがわ 加名。

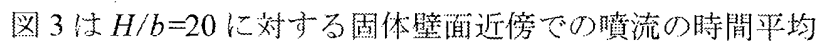

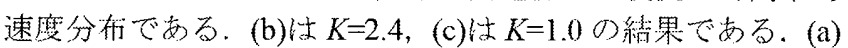

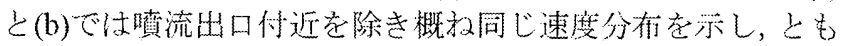
に噴流はコアンダ効果により壁面側に引き害壮りれるいわ Wる付着聼流上なっている。だし，例えば $x / b \doteqdot 40$ 以隆に 扔いて(a)では尔找流速に分布が見られるのに対して(b)では 確認五困難になる。一f，(c)では図 2(c)同様，算流䁷が小

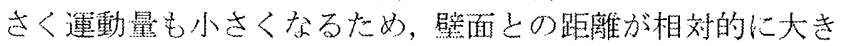

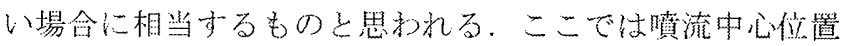

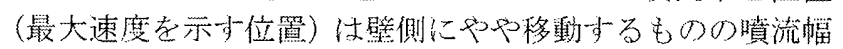

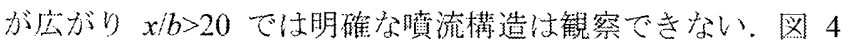

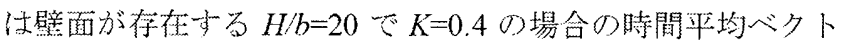
ル図である。 $K=0.4$ の条件ではシンセティックジェット形成

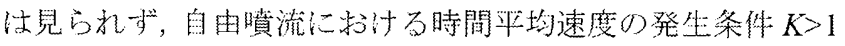




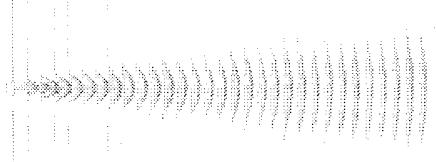

(a) Continuous jet

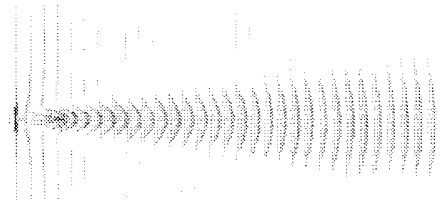

(b) $K=2.4$

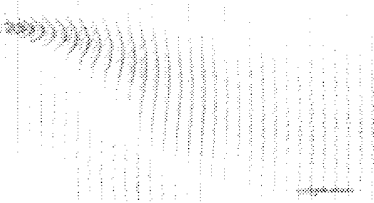

(a) Continuous jet

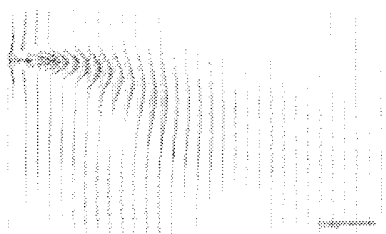

(b) $K=2.4$

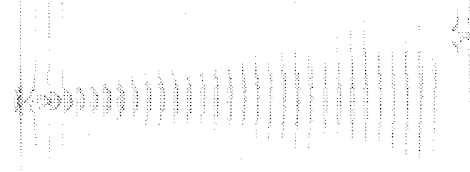

(c) $K=1.0$

Fig.2 Time-averaged velocity field $(H / b=\infty, R e=133)$ (c) $K=1.0$

Fig.3 Time-averaged velocity field $(H / b=20, R e=133)$

Fig.4 Time-averaged velocity field $(K=0.4, H / b=20, R e=133)$

としている Holman ら $ら^{(0)}$ の結果とも対底するる。

図 5 は噴流下流での流量变化であり, 横軸注 $x / b$, 縦軸付 連続嗔流とシンセティックジェットを比較するため有次无 の二次元流量 $Q\left[\mathrm{~m}^{2} / \mathrm{s}\right]$ で表した（a)には図 2 に対応する䜿眼

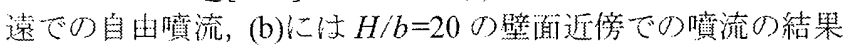

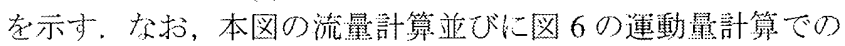
$y$ 万泪積分範网は簡単のため-20<y/b<10 とした。 図 5 (a)では すべての条件で流れが下流側に進むにつれてエントレイン メントに上り流量が传ぼ直線的に增加していることがわか 万. $K=1.0$ で平均流は発生しているものの形成される平均流 量は小さい， $K=2.4$ の流量変化の公配は連続喃流の場合亡比 較しても大きく,$x / b>15$ では $K=2.4$ の流量が連続噴流を上回 つている.また, シンセティックジェットのそれぞれのKに

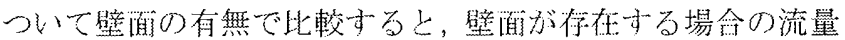
堌加率は存在し宛い場合に比心゙，小さくなっている。特に(b) の $K=1.0$ では， $x / b>15$ で流量の増加はほ上んご見られない。

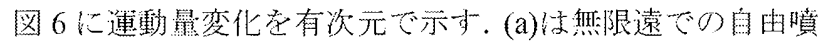
流，(b)は $H / b=20$ の壁目近傍での結果である、い子れの場合

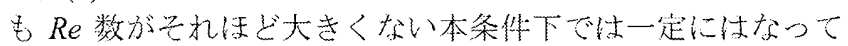
招ら尃，下流にいくにしたがってわずかに減少している。(a)

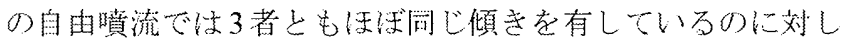
て, 壁面㔔存在子石(b)では $K=2.4$ の場合は他に比較して減衰 率が大きいことがおかる。，K=2.40場合性再循環頒域に連続 噴流の埥合上りも强い洞在形成寸るため，大きなせん断力が 働くものと推察される。またこれらのことから自由噴流の

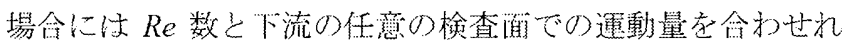
ば，すなわち逨続噴流の運動量と等しくなる $K$ の条件を見つ

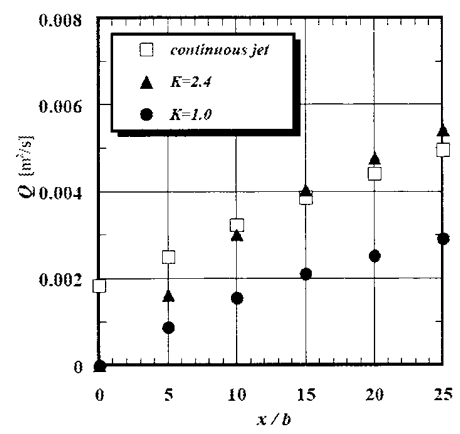

(a) $H / b=\infty$

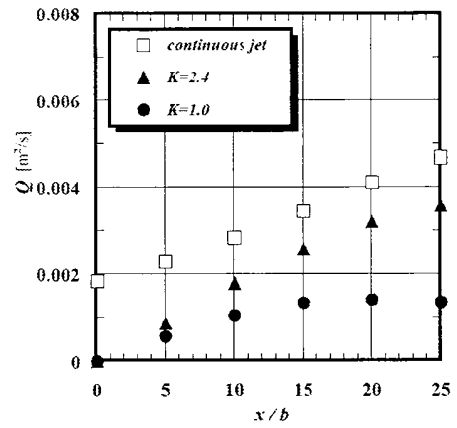

(b) $H / b=20$
Fig. 5 The variation of $Q$ with $x / b\left(U_{j}=0.5 \mathrm{~m} / \mathrm{s}, U_{0}=0.5 \mathrm{~m} / \mathrm{s}\right)$

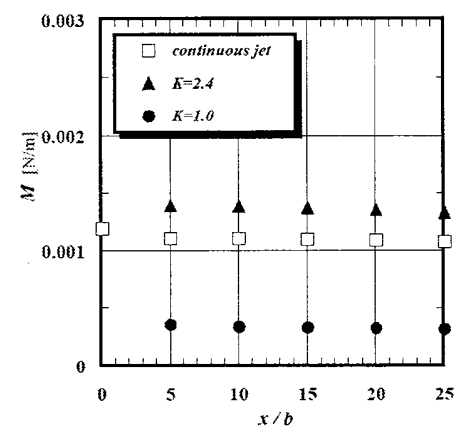

(a) $H / b=\infty$

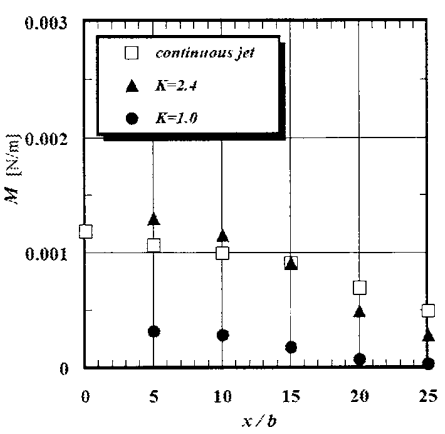

(b) $H / b=20$
Fig.6 The variation of $M$ with $x / b\left(U_{J}=0.5 \mathrm{~m} / \mathrm{s}, U_{0}=0.5 \mathrm{~m} / \mathrm{s}\right)$

け逨続噴流とシンセテイックジェットを比較对ることは妥

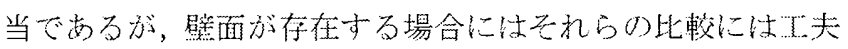

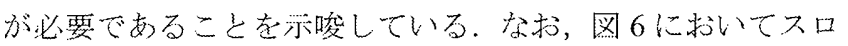
ットH口でのシンセティックジェットの運動量 $M_{0}$ 㤬 Tensi らの定義(4)によれば $M_{0} \fallingdotseq 0.006$ でする。吹き出し時の運動量

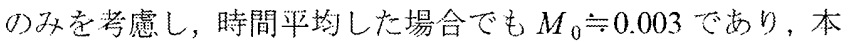
計算から外接される值の2 倍程磨になっている。したがって, シンセティックジェットの連動最の定義については今後,さ らなる議論汃必要である。

\section{4. 結論}

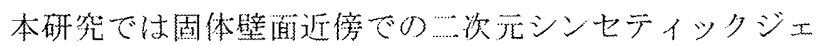
ットの流動特性在調心゙た。 $R e=133$ の条件下で数值シミュレ ーション孝行った。主な結論を以下に示吉.

1. シンセティックジェットの速磨分布は $K$ に大きく依存 するため，噴流唯壁面に付着するか否か子小 $K$ に依存する。

2. シンセティックジェットの流量增加率は $K$ 上壁馗の有 無に依存する。

3. 運動量の変化について, 自由顀流では連続噴流, シンセ ティックジェットしもほぼ同じ勾配で努るのに刘して, 壁目成存在寸当場合は減衰率が $K$ に依存于る。

本研究意遂行するにあたり三熏大学 社河内敏教授，

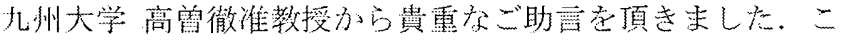
こに記して謝意老表します。

\section{考文献}

(1) Duvigneau, R. et al., Journal of Fluid Engineering, Vol.129 (2007), pp.825-833

(2) Whitehead, J. and Gursul. I., AIAA Journal. Vol. 44, No.8 (2006). pp. $1753-1766$

(3) M. Amitay et.al AIAA Journal, Vol. 39, No.3 (2001). pp.361-370

(4) Tensi. J. et al, Joumal of Visualization, Vol.5, No.1 (2002), pp.37-44

(5) Holman, $R$ it al., AIAA Journal, Vol. 43, No.10 (2005), pp.2110-2116

(6) Zhang, P.F. and Wang, J.J., AIAA Journal, Vol. 45, No.5 (2007), pp.1058-1065

(7) Shuster, J.M. and Smith. D.R., Physics of Fluids, Vol. 19-045109 (2007), 1-21 